\title{
An Essay on \\ the Free Movement of Peoples
}

\author{
ROBERT F. BARSKY
}

\section{Abstract}

This article argues that debate on Bill C-31 should, in fact, focus upon the fact that it is impossible to determine the veracity of refugee claims using current methods of adjudication, that Canadian refugee and immigration legislation is incompatible with the international conventions, declarations, and norms upon which it is said to be based, and the absurdity of restricting the free movement of peoples. Arguing that the immigration and refugee system already favours free movement for the rich and the well-connected, and that the proposed legislation will further punish those who already suffer greatly from current restrictions, the author suggests that Canada should work to assist those who desire to move by eliminating obstacles such as thirdcountry clauses, visa restrictions, and prohibitively priced airline tickets, and that rather than penalize those who assist in people's natural desire to move around, Canadian officials should help find ways to encourage the movement of peoples on whatever grounds they themselves think appropriate.

\section{Résumé}

Cet article maintient que le débat autour du projet de loi c31 devrait en fait être dirigé sur les questions suivantes: l'impossibilité de déterminer la véracité des demandes d'asile en utilisant les méthodes actuelles de détermination, l'incompatibilité qui existe entre, d'une part, la loi canadienne sur l'immigration et le droit d'asile et, de l'autre, les Conventions, Déclarations et normes internationales sur lesquelles elle est sensée être basée, et, par ailleurs, l'absurdité d'essayer de limiter la libre circulation des peuples. Arguant que le système de l'immigration et du droit d'asile favorise déjà la libre circulation des gens riches ayant de bonnes relations, et que la nouvelle législation va punir encore plus ceux qui souffrent déjà beaucoup sous les restrictions existantes, l'auteur suggère que le Canada devrait travailler à aider ceux qui désirent se déplacer en éliminant les obstacles tels que les clauses des pays tiers, les restrictions sur les visas et les billets d'avion à prix exorbitants, et qu'au lieu de pénaliser ceux qui facilitent la réalisation du désir naturel des gens de se déplacer, les officiels canadiens devraient plutôt aider à trouver des moyens d'encourager la circulation des gens quelles que soient les raisons que ces derniers considèrent comme appropriées.

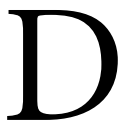
ebates about immigration policy often focus upon the relationship between proposed laws and what came before, as opposed to more useful analysis of what is really at stake: the movement of peoples within and across artificial national and international boundaries; the lines between public and private property; and the enforced divisions between areas where human beings are allowed to be free, and areas in which they are, for whatever reason, trapped against their will. Along the way, it would be useful to analyze the relationship between peoples occupying different kinds of marginal spaces within and beyond our own country, notably transitional spaces like airports, judicial spaces like courtrooms, and privileged spaces like private homes. To think in these terms forces us to ponder fundamental issues underwriting proposed bills such as C-31, and should lead us to consider the perversity upholding laws designed to deny free movement to some people - the poor, the suffering, the "other" — while considering it a fundamental right for others-the rich, the well-connected, the powerful, and the "not-other." As presently construed, the current migration system treats the "others" as charity cases; we are made to believe that Canada benevolently assists people who have been made to suffer in their own countries. This makes us very generous and very tolerant; we feel pretty good about ourselves and about our country, and by extension we are led to support c-31, which proposes to regulate how people can come into "our" 
space, our country. As we read in the outset of this bill, "The objectives for the refugee program recognize that refugee protection is, in the first instance, about saving lives and that providing fair consideration to those who come to Canada claiming persecution is a fundamental expression of Canada's humanitarian ideals."

A second look at our benevolence and the noble efforts aimed at "saving lives" demonstrates the wrong-headedness of such views by the purely legalistic standards employed to consider their cases, or even in the economic terms generally favoured by those on both sides of this argument. For the sake of those who think that our economy ought to regulate our ethics, it's worth pointing out that refugees arrive in our country generally as a last resort, and although they are in desperate need of assistance, they are essential not only for our economy, but for the diversity upon which contemporary society thrives. Furthermore, a look at global economics demonstrates that our standard of living is partially dependant upon the types of corporate forays into the cheap labour wells and the unregulated environmental buffets of the Third World that create refugee problems. Our national system is built upon the erection of barriers that affect migration well beyond our borders. And our very social structure is built upon the fruits of First World control over distant lands. This doesn't mean that we ought to have more liberal laws about migration to compensate for our illiberal economic system; instead, we should really question what it means to legitimize barriers, like Bill c-31, which are aimed at limiting fundamental human rights, such as freedom of movement.

It could be argued that to condemn refugee policy is a poor choice to make in a country as generous to refugees as Canada is perceived to be. And granted, the procedure to adjudicate refugee claims is superior to the one used in the United States and (with a few exceptions) in Europe. Unfortunately, this isn't saying much. Knowledge of the international refugee situation should incite persons in the First World to throw open their borders, rather than fall for the false arguments that sell measures such as the Third Country clause that $\mathrm{C}-31$ takes for granted, the hardened airline and visa rules that ensure that those most in need will never see the light of a Canadian hearing room, and the preposterous penalties proposed to halt the "illegal" transportation of people seeking assistance. For, as serious research demonstrates, refugee claimants don't simply move to Europe or America to gather up the gold that lines the streets (a look at domestic poverty should be enough to diffuse that argument). Indeed, the resistance of even the most heavily persecuted claimants to the idea of leaving their home, their family, and their friends is in the vast majority of cases monumental, and their knowledge of Canada (or other host countries) tends to be extremely sparse. This only makes sense; why come and freeze in a Canadian winter, in some small apartment in a crummy area of a big unwelcoming city? Because our society hands out free money to foreigners? Hardly. Because some people might wish to come to our country to have a life, to make a buck, to raise a family? Sounds pretty much like everyone else to me.

My own studies have shown that people suffer considerably before making the move to another country, like Canada, and that once here they suffer again, but they work hard to make the next generation survive. This is indeed a kind of principle that is inscribed into a primary text for refugee determination, the UNHCR's Handbook on Procedures and Criteria for Determining Refugee Status, which suggests in chapter 1, article 39, "It may be assumed that, unless he seeks adventure or just wishes to see the world, a person would not normally abandon his home and country without some compelling reason." My experience confirms this point; most of the claimants I've interviewed over the years took a decided financial loss when they came to Canada, for the most part willingly, in exchange for safety and protection for themselves and their families. This is not to say that those granted refugee status in Canada don't strive to succeed. Quite the contrary. Studies over the years by federal and provincial agencies have consistently shown that in virtually every respect refugees make for better Canadians than Canadians do, by all the normal criteria of measurement (less likely to go to prison, less likely to be unemployed, more likely to educate their children, and to a higher degree, less inclined to use social services, and more likely to employ other Canadians). In short, the number of restrictions on necessary migration is unnecessarily high, and indeed the arguments generally employed to erect or bolster the kinds of restrictions outlined in Bill-C-31 tend to be founded upon phony premises, as opposed to concrete research that the government itself commissions.

But I don't wish to make an argument for softening Bill $\mathrm{C}-31$, even as I nod in agreement with the effort it makes to facilitate the claiming process for some "categories" of refugees. I don't even wish to promote a liberal policy towards immigrants and refugees, even though it would certainly be of some solace for a small number of persons considered eligible to benefit from such a remedy. My real interest is elsewhere, and it leads me to one underlying hypothesis, one idea, one proposal, which is on the one hand so obvious that it doesn't even deserve mention, and on the 
other hand so radical that it cannot even be uttered in discussions about refugee policy without scornful or dismissive rebuttals: People have the inalienable right to move around as they wish, for whatever reason they think appropriate. Period. Borders between states are an aberration, the idea of the nation is reprehensible in its consequences, and restrictions imposed upon people who wish to travel from one region of their world to another are absurd and hurtful. Bill C-31 is wrong because it is built upon a premise that simply makes no sense, that the "state" should exist because it is in some way a natural form of organization for human beings. In fact, as Chomsky points out,

The state system is a very artificial system. In its modern form it developed in Europe, and you can see how artificial it is by just looking at European history for the last hundreds of years, a history of massacre, violence, terror, destruction, most of which has to do with trying to impose a state system on a society to which it has very little relation. As Europe expanded over the rest of the world, pretty much the same thing happened-you look at Africa, India, Asia, any place you go, they've got these boundaries which are the result of coloring different colors on the map that usually have to do with European colonization. They cut across all kinds of communities and interests and they bring people together who have nothing to do with each other.

The result of this state system, as Chomsky points out, is violence, warfare, struggle, oppression, and some

very sharply skewed distribution of power internally. The concentration of power inside usually takes over the state for its own good. It suppresses other people, suppresses people outside, etc. So we're stuck with this state system, for a while, at least. But we shouldn't expect it to be permanent. In fact, if it's a permanent condition, it isn't going to last very long because it's a lethal system. It's a miracle that it has survived as long as it did ... From every point of view the state system looks artificial in the sense that it's unrelated to human needs and imposed by certain interests and power distribution (Language and Politics 745).

From this perspective, the problem of refugee studies is a secondary one, because it grows out of a more fundamental issue, relating to the distribution of power and the organization of peoples in contemporary society. For this reason, I would simply suggest that the domain of refugee studies shouldn't exist, the category "refugee" shouldn't exist, and people employed to limit the movement of persons from one place to another should be occupied with other matters, such as the problem of assisting those who would like to move to another region but cannot on account of limited resources.
A related hypothesis, clearly demonstrated once again by any number of research projects, not to mention experience or common sense, is that any attempt to adjudicate claims is not only inappropriate, but necessarily flawed, and this for a whole host of reasons that, if we think about it, hardly deserve mention. First, we couldn't possibly tell whether claimants "deserve" status according to the set of laws in place to determine such things, because it isn't possible to apply the existing criteria to all cases in a consistent or justifiable manner. Second, we cannot employ the tools of discourse analysis, no matter how sophisticated, to distinguish between truthful and untruthful statements in refugee hearings except at a very superficial level (contradictions, inconsistencies). Third, there are too many conflicting interests involved in groups that include a claimant, an interpreter, an adjudicator, and a lawyer for there to be much more than a mutual display of efforts aimed at legitimizing the positions of each person involved. And fourth, the obstacles placed before those who don't replicate the image we have of ourselves are so vast and insurmountable as to render moot any discussion about ways of determining such silly categories as the "truth" of a claim. Do contradictions in testimonies offered by people who have had their genitals electrocuted by government employees in their country of origin prove that they are "lying" to government authorities in the host country?

Granted, laws do exist to establish legal categories in the present-day system, but does abiding by the laws of the land mean that governments can disregard international conventions and treaties to which they are signatories? If we were to take certain international conventions and treaties seriously, conventions to which most countries of the world are party, then we should be looking for ways to facilitate rather than impede free movement, as we shall see. Finally, and this returns us to the initial hypothesis, people simply don't have any business restricting other people from moving around, even if the motivation to do so is crass economic gain, because the fact is, free movement is good for individuals and good for societies in every discernible way. This being the case, I'd also suggest that the road to radical change - that is, the movement towards what is conveniently regarded as "idealist" or "utopian" and therefore not worth pursuing - is my sense that we can and should do better than we're doing, and that eliminating barriers from persons who would move if they could might be one small step in that direction. It would be a significant improvement, if only because it would mean that populations wouldn't necessarily have to be subjected to the lunatic ideas of power mongers or hurtful economic systems, because 
they would have the knowledge required and the resources needed to move to another more comfortable space. This article should be a short one, therefore, and debate about Bill c- 31 should be similarly constrained, because the very idea that persecuted peoples should have to justify their flight from persecution before our legal or administrative systems is, by any reasonable measure, hurtful to all people, especially of course the poor, and counter-productive for all members of society except for those who do the oppressing.

\section{Simplifying and Clarifying Migration Procedures}

This type of approach won't be sufficient for those in search of "protection" from people in flight, or those who hope to "protect" the jobs of "ordinary Canadians" from "illegal" migration, because no matter how obvious it is that people ought to move around as they wish, there remains a whole range of people and organizations who have interests, ultimately power interests, that will demand protection against those who have legitimate claims against them; the people who work to protect these interests do so by resorting to a series of false or hypocritical arguments, like the ones we find in Bill c-31. For this reason, it's worth identifying a few of the really nefarious passages of this bill and then to show-again for those who prefer to support arguments with reference to, say, legal documents- that even according to the refugee laws and conventions employed to legitimize our own refugee determination system, Bill $\mathrm{C}-31$, like all bills and acts that have preceded it in this country, don't meet their own criteria. As such, they really aren't much more than purveyors and upholders of a status quo that turns out to be extremely oppressive for all but a small proportion of the earth's inhabitants.

In the document "CIC Canada-Bill c-31: What is New in the Proposed Immigration and Refugee Protection Act" we are treated at the very outset to the idea-implicit in the fact that we need to replace the current act because it "dates back to the 1970s"- that laws get worn out, somehow, and need to be "updated." This is interesting when one considers laws about fundamental human rights, say, the Canadian Charter of Rights, the American Bill of Rights, or even our own constitution, because it suggests that fundamental human rights aren't so "fundamental" after all, and that even though the Immigration Act exists to fulfill our obligations under previous conventions, it can somehow get worn out. How can we legitimize building a society upon the authority granted by a constitution, even as we challenge the legitimacy of historical documents like constitutions on the grounds that laws wear out? Bill c-31 doesn't have any answers, but it does seem to suggest that laws get worn out because they get too complicated over time, on account of all the amendments and changes brought to them, which leads to the "the need for immigration policy and legislative reforms expressed in a clearer, simpler and more coherent Act." Let's pursue this line for a moment, because it's more promising than most.

Bill c-31 runs 150 or so pages, so it doesn't seem to qualify according to its own criteria of clarity or simplicity; but there are other legal instruments that do, such as the Universal Declaration of Human Rights, which, I imagine, most Canadians support, or would support, if its ideas were diffused. There are a few articles in here that apply to the Bill c-31 terrain, such as article 5, which simply states, "No one shall be subjected to torture or to cruel, inhuman or degrading treatment or punishment." Most people would agree with that, and it's simple enough, so we could scrap our immigration act and simply uphold that principle, which would save many people from a lot of suffering, and might even help change the political systems that create oppression and persecution, because everybody would know take that principle as fundamental and necessary, so they'd expect it, or demand it, from those empowered to act on their behalf.

Perhaps this clause isn't precise enough, however, since we are also talking in c-31 about movement of peoples who have been affected by abusive treatment, so let's look to my personal favourite, article 13, which upholds the very clear, simple and coherent idea that: "(1) Everyone has the right to freedom of movement and residence within the borders of each state. (2) Everyone has the right to leave any country, including his own, and to return to his country." For further precision, we might also add article 14, which, once again, is as clear as can be on the issue of asylum: “(1) Everyone has the right to seek and to enjoy in other countries asylum from persecution." To ensure that this is properly applied, we could end the act with article 2, which states, "This right may not be invoked in the case of prosecutions genuinely arising from non-political crimes or from acts contrary to the purposes and principles of the United $\mathrm{Na}$ tions."

Some legalistic soul might claim that the declaration doesn't have any more than a moral hold over our society, that even though we apparently support it, we also have to have specific legislation to make it work, such as the international treaties and conventions to which we are signatories. Luckily, these legal instruments tend to be rather simple and clear, so they are indeed worth a look. Since the framework and indeed the very legitimacy of our Immi- 
gration Act is based upon the 1951 UNHCR Convention relating to the Status of Refugees and its 1967 protocol, then we certainly aren't resorting to an irrelevant text if we choose this one as a point of reference.

Article 1 of that convention says that a refugee is someone who, "owing to well-founded fear of being persecuted for reasons of race, religion, nationality, membership of a particular social group or political opinion, is outside the country of his nationality and is unable or, owing to such fear, is unwilling to avail himself of the protection of that country; or who, not having a nationality and being outside the country of his former habitual residence as a result of such events, is unable or, owing to such fear, is unwilling to return to it." If, against my personal will, someone were to insist that free movement is not an inherent right, and that states do and should exist, then this definition could apply, which means that someone should only have to claim to fear persecution, which couldn't really be questioned (how can you question if someone has, according to his or her experience, suffered? How could you prove it one way or the other?), and this person should be granted asylum. Again, I don't favour this route, because it suggests that we ought to adjudicate things, but since those who support laws like C-31 like to be legalistic, then they should at least be reading the legal texts that underwrite the laws that they are choosing to support.

There might be other grounds for opposing the approach I'm setting forth here. For instance, I would grant that if Canada alone decided to promote free movement, we'd likely have a few more citizens next year than had been expected, and there would be some infrastructure problems in the short term, at least. As for the elimination of states and the organization of society around other principals, this would have to be part of a larger effort, which is worth working towards, in my opinion, if only in terms of our attacking organizations and instruments of repression. It is also true that if we were to follow the more legal route suggested by the letter of the convention, then there's the problem that we're not accounting for Canadian racism, xenophobia, or the many wrong-headed ideas that are thrown about, describing how "others" steal "our" jobs, for example, and it doesn't pander to government efforts to blame the countries' woes, or union efforts to blame the companies' woes, or lawmakers' efforts to blame the municipalities' woes, upon the "other." To address the real issues of this hypothetical "other" would require that we face the consequences of the innate inequality of the current economic system - unemployment, unequal distribution of wealth, a growing distance between the rich and the poor, and between rich and poor nations - which is not addressed in C-31, even though it is at the root of the problem that it tries to address. Instead, C-31 suggests that the solution lies in reducing the "flows" of "illegal" migrants, in impeding our international (not to mention moral) obligation to assist those in need, and in halting things that we lawabiding citizens so loathe, like "queue jumping." The fact that it's kind of hard to jump when you're starving, tortured, raped, and denied fundamental rights for some reason doesn't really matter.

\section{Violations of International Principles at Every Level}

It's interesting to look at some of the details of $\mathrm{C}-31$ to see how it proposes to act on these "problems," because over and above its blatant efforts aimed at ensuring that Canada doesn't even live up to international standards for refugee adjudication, it also puts into effect a range of policies aimed at violating international law on a larger scale. For example, $\mathrm{C}-31$ distinguishes between refugees on the basis of such ideas as how they came to Canada, and who helped them succeed in this aim. This is interesting in terms of the convention's article 7, which insists, "Except where this Convention contains more favourable provisions, a Contracting State shall accord to refugees the same treatment as is accorded to aliens generally," and article 16, which insists, "1. A refugee shall have free access to the courts of law on the territory of all Contracting States; 2. A refugee shall enjoy in the Contracting State in which he has his habitual residence the same treatment as a national in matters pertaining to access to the Courts, including legal assistance and exemption from cautio judicatem solvi; and 3 . A refugee shall be accorded in the matters referred to in paragraph 2 in countries other than that in which he has his habitual residence the treatment granted to a national of the country of his habitual residence." This article makes it clear that anyone making a claim should have a proper hearing, and no mention here is made of how she managed to make it to Canadian territory, since this really shouldn't be an issue. Indeed, since it's unlikely that someone who has had difficulty in his country of origin will be able to follow "normal" channels to come to Canada to benefit from an internationally recognized right, then any attempt to distinguish between refugees, or, for that matter, immigrants, in terms of limiting or denying them access to a hearing, is illegitimate.

This is not the line taken by the proposed law, of course. Indeed, the "law-abiding" spirit of $\mathrm{C}-31$ has some terrific legislation that aims to send out the real message of how Canada considers poor people who try to move around; 
they are criminals, unless proven otherwise, and therefore should be incarcerated at the whim and will of the bureaucrats. "Reasonable" grounds for incarcerating people, which are the present criteria, tend to be easy to find in the case of refugees, as we saw with the Chinese who were incarcerated en masse in Vancouver last year. Bill c-31 also adds that "persons inside Canada, with the exception of persons on whom refugee protection has been conferred and permanent residents, who fail to establish their identity for the purpose of a proceeding under the Act may be subject to arrest." The potential for abuse is breathtaking, given the problem of procuring documents if one has been persecuted in a country of origin. For some reason, C-31 insists very heavily upon this point:

IRB required to take into account a claimant's lack of identification when assessing credibility. Under the current Immigration Act, lack of identification only becomes a factor in the event of a split decision by the IRB panel. It is a published practice of the IRB, however, that lack of documentation is a factor in the assessment of a refugee's credibility. Bill c-31 increases transparency by expressly stating that lack of documentation, absence of a reasonable explanation for lacking documentation, and failure to take reasonable steps to obtain documentation are factors that must be considered by the IRB when assessing credibility.

This is one of the many areas in which a very simple hypothesis applies, and should always be borne in mind when considering treatment of those judged by some group or another to be a suffering other: To the degree that someone is really in need of assistance, our system will act to ensure that such a person is refused.

It's already hard to believe that under the current Immigration Act it is illegal to use fraudulent documents, but consider that Bill c-31 expands this to also make it an offence to possess fraudulent documents. It is only obvious that if you're resorting to fraudulent documents you may be following (bad) advice from someone who saved your life, or you may be doing so because you couldn't procure authentic documents, a fact that wouldn't be terribly surprising if you'd been subjected to torture in the country of origin. The fact is, if you have identification, you probably left the country of origin by a simpler route than if you were forced to procure false documents, or if you were advised to destroy your documents en route to Canada. If you came by illegal means, then chances are you couldn't come by legal means, because illegal means tend to cost more, are more dangerous, and are far less reliable. And if you've given false testimony, you probably have received faulty information about the adjudication process, perhaps from somebody who was well-meaning and who otherwise helped out considerably with some element of the claim, like travel, which made his or her advice seem acceptable.

Instead of taking this obvious point into account, the proposed law becomes even more draconian: "Under Bill C-31 the offence of making misleading statements will include the withholding of material facts in regard to any decision-making. This clarifies that the withholding of material facts is a form of misrepresentation. Additionally, the offence of counselling misrepresentation, currently limited to the making of refugee claims, is broadened under Bill c31 to apply to all immigration matters." Who are claimants supposed to believe: those people who tortured them, or refused them permission to leave their country, or the nonofficial people who actually helped them? These people who help persecuted peoples to fulfill their dream of escaping persecution, since official channels are so limited as to help but a tiny proportion of those in need, are by our standards criminals on par with murderers, according to the new proposals, which include the possibility of life in prison for persons caught "smuggling" ten or more persons.

The obscenity of this idea is blatant: what are people who are ineligible for legitimate travel but eligible for refugee status in Canada supposed to do? What if they can't get a passport, a visa, or the money required to leave the country? What if they are "wanted" for some crime in their country, like fighting against a dictatorship? Do we seriously think they'll be allowed to pass through the airport in the nation's capital unnoticed? Or through a border crossing?

The convention doesn't talk much about the problem of finding a safe haven in the first place, but it does offer standards regulating related issues, such as the rights of those who make claims in signatory countries, in article 28 , which sets out the principle that

(1) The Contracting States shall issue to refugees lawfully staying in their territory travel documents for the purpose of travel outside their territory unless compelling reasons of national security or public order otherwise require, and the provisions of the Schedule to this Convention shall apply with respect to such documents. The Contracting States may issue such a travel document to any other refugee in their territory; they shall in particular give sympathetic consideration to the issue of such a travel document to refugees in their territory who are unable to obtain a travel document from the country of their lawful residence; and (2) Travel documents issued to refugees under previous international agreements by parties thereto shall be recognized and treated by the Contracting States in the same way as if they had been issued pursuant to this article. 
The message here is clear: people aren't criminals just because they're exercising their internationally recognized right to free movement, and they aren't to be treated as such. And people who help them exercise their right to make a claim ought not be punished, necessarily. Instead, they should perhaps be hired by the Canadian government, or by aid organizations concerned with helping those in need, to find a way to travel to their destination. It is taken for granted that we ought to adopt a policy similar to the one whereby municipalities allow people to drink, allow people to stay out late in bars, and then either close down, or don't operate, the late-night public transportation that is essential to ensure that they can get home safely. Instead, police are stationed near bars to catch those who have chosen the logical way home, their own vehicle. Rather than putting an effort into assisting with the transportation of those in need of help, punitive, expensive policies are enacted that catch people and fine them, or don't catch people but later have to clean up the mess caused by ensuing traffic accidents. The point is, people wouldn't have to resort to "illegal smugglers" - who in some cases render a very valuable service, by the way-if visa restrictions, airline penalties, and inordinately expensive travel costs from the Third to the First World weren't the norm.

All of this is rather hard to fathom, perhaps, but one must consider that the very idea of "illegal entry," or coming to another place by illegal means, is logically inconsistent if we are dealing with refugees, and the convention recognizes this clearly. Article 31 states that

(1) The Contracting States shall not impose penalties, on account of their illegal entry or presence, on refugees who, coming directly from a territory where their life or freedom was threatened in the sense of Article 1, enter or are present in their territory without authorization, provided they present themselves without delay to the authorities and show good cause for their illegal entry or presence. (2) The Contracting States shall not apply to the movements of such refugees restrictions other than those which are necessary and such restrictions shall only be applied until their status in the country is regularized or they obtain admission into another country. The Contracting States shall allow such refugees a reasonable period and all the necessary facilities to obtain admission into another country.

The ideas of "penalties" deserves pause. First, it ought in my sense to include user fees; while we're mistreating those who exercise their right to move around, it seems acceptable to most that we might as well add user fees, that is, we should add debt to the list of woes from which refugee claimants have suffered. And for those who don't obey the rules, things get even worse:
Bill C-31 increases fines for general offences such as failure to comply with a term or condition imposed under the Act, escaping lawful custody or detention, and employing persons not authorized to work (on indictment from $\$ 5000$ to a maximum of $\$ 50,000$; on summary conviction from $\$ 1000$ to a maximum of $\$ 10,000$ ).

The convention is, once again, clear on this: article 29 states, "(1) the Contracting States shall not impose upon refugee duties, charges or taxes, of any description whatsoever, other or higher than those which are or may be levied on their nationals in similar situations." There seems to be the belief, not unreasonable, that to help people integrate into our society, they may as well get used to the idea of crushing debts.

\section{Keeping the System Transparent}

There are two hopes for those who have been subjected to the abuse regularly heaped upon those we consider marginal, such as refugees: one is to erect a solid appeal procedure that can overturn some of the misguided decisions regularly handed down, and the other is to make the public aware of what goes on in these hearings by allowing some access to documents if the claimant is in agreement. As to the first, the way that C-31, and other bills of its kind, ensure that it'll be the poor who will suffer is to limit the rights refugee claimants have to appeals, and then limit the rights they have even if they are granted an appeal. For instance, there is a new proposal in C-31 suggesting that there should no longer be automatic stay of removal for judicial review of refugee decisions: "The current Immigration Act provides a stay of removal in most cases when judicial review is initiated following unsuccessful refugee applications. Although there is no automatic stay in Bill c-31, the new regulations will provide such a stay subject to a two-year sunset clause." This comes in addition to all sorts of ways of limiting appeal rights to claimants and to sponsors, already threatened under the current system. The potential for abuse, and the spectre of misused discretion, grows when vague passages are added to the collection of ways to discourage or rule out people; to take but one example from C-31: "No appeal by sponsors in cases of misrepresentation except in respect to a sponsor's spouse, common-law partner or child." Or, worse still, "Currently, the IAD can reopen an appeal at any time to hear new evidence. There has been an increase in requests for re-openings and there is concern that this is often a tactic to delay removal. Under Bill C-31 the reopening of appeals may only be granted on the basis that the IAD failed to observe a principle of natural justice and only if the appellant is still in Canada. This 
provides some finality to the appeal process." Does it ever! And it even applies to overseas visa refusals, which, in my experience, is as unpredictable and inconsistent a procedure as could be imagined: "New leave requirement for judicial review of overseas visa refusals. This makes judicial review for overseas cases consistent with in-Canada cases which all require leave. This will also help to ease resource requirements and Federal Court backlogs as the number of overseas applications for judicial review has risen substantially over the last few years." The problem with this is that when the rate of appeals goes up, it's often because decisions are erroneous. And the fact that repeat claims will no longer be allowed, and that claims will be eligible for termination in light of "new information" brought forward, again heightens insecurity and makes it such that people who have received inaccurate information about the claiming process will be penalized and will be left without recourse. Obviously, recourse for flawed decisions isn't necessary if original decisions make sense, but in so many cases they simply don't, and this despite the presence of two members of whom only one needs to see the validity of the case. To make matters worse now, C-31 is proposing singlemember panels, which "would be the norm for all IRB divisions with ability for the Chairperson to appoint threemember panels (except for the Immigration Division) where appropriate." Given the studies that have turned up overt racism, errors of law, errors of judgment, and a range of game-playing inside the hearings, the combination of too much discretion, one doesn't have to work hard to imagine the potential for abuse in a system that relies upon single-panel hearings and limited possibilities for appealing asinine decisions.

On the second issue, ensuring that people have access to information about what goes on in IRB hearings, so that they can understand some of the errors of judgment and law that occur therein, or so that they can themselves prepare for a hearing, is to make information about what goes on in these hearings accessible. C-31 proposes to curb this, by offering

new provisions for non-disclosure of information at IRB hearings. Currently, the Minister may apply to the Federal Court to protect information with respect to appeal hearings. There are no provisions to protect sensitive security information during immigration inquiries for determining admissibility. Under Bill c-31, the Minister may apply for non-disclosure of information at an appeal or admissibility hearing. The presiding IRB member would make a determination on such requests by following the same rules followed by the Federal Court when reviewing security certificate cases. The new provisions expand the ability to protect information and provide a simpler process that eliminates the need, at IR в hearings, to seek recourse to the Federal Court. In the interests of natural justice, the person will receive a summary of the information or evidence as well as an opportunity to be heard regarding their case.

Once again, the potential for abuse of this power is vast, and this problem is probably heightened by the new in camera rules proposed in this bill, which are to apply to all four divisions of the IRB.

\section{Safe Third Country}

The next area that Bill c-31 takes for granted concerns an idea that previously surfaced in another twisted bill known as C-55. This area deserves special mention because it is one of a growing range of weapons (prohibitive costs of tickets for travel from the Third to the First worlds, visa restrictions, fear mongering) used against those who would dare try to set foot upon our soil to effect their internationally recognized right to claim status. C-55, adopted into C-31, legalizes the category of the "safe third country," a notion that violates the fundamental principle of the convention, article 33, concerning the prohibition of expulsion or return (refoulement): “(1) No Contracting State shall expel or return ("refouler") a refugee in any manner whatsoever to the frontiers of territories where his life or freedom would be threatened on account of his race, religion, nationality, membership of a particular social group or political opinion." Practising sneaky refoulement, already widespread, will get worse with c-31. For instance, "Airlines to be able to provide prescribed passenger information to cic. This provision will be used to identify passengers who are inadmissible to Canada or for whom there is a warrant for arrest. Passenger information will only be used in the administration or enforcement of the Act." There is no such provision under the current Immigration Act.

As far as the convention is concerned, the "safe third country" clause is illegitimate because claimants have rights to make claims where they wish, subject to a small number of guidelines. Goodwin-Gill (The Refugee in International Law, 1996) notes that article 31 comes closest to dealing with this issue: "Refugees are not required to have come directly from their country of origin, but other countries or territories passed through should also have constituted actual or potential threats to life or freedom." What is unclear in section 31 "is whether the refugee is entitled to invoke article 31 when continued flight has been dictated more by the refusal of other countries to grant asylum, or by the operation of exclusionary provisions such as those on safe third country, safe country of origin or time limits" (152), all of 
which is of special concern for the countries in question. The "safe third country" clause has been the subject of much contestation, and the description of this clause takes many forms, depending upon the country in question. In Canada, legislation covering this issue came into effect in 1993 with the passage of Bill C-86, which states,

46.01 (1) A person who claims to be a Convention refugee is not eligible to have the claim determined by the Refugee Division if the person

(a) ...

(b) came to Canada, directly or indirectly, from a country other than a country of the person's nationality or, where the person has no country of nationality, the country of the person's habitual residence, that is a prescribed country under paragraph 114(1)(s).

As Goodwin-Gill notes, however, the "safe country" provisions of the Immigration Act have existed since 1988, but "were not implemented for a variety of practical and political reasons" (ibid. 336). Nevertheless, agreements have been made (or are under negotiation) between countries, including Canada and the U.S., and Canada and Europe, to move in this direction. Already the Dublin and Schengen conventions have as objectives "to determine which participating State is responsible for deciding the asylum claim of an individual within the area of application; to provide in appropriate cases for the readmission of the individual, and for the exchange of information; and to confirm the responsibility of the State for the removal of unsuccessful applicants from the European Union or Schengen territory, as the case may be" (337). And Loescher notes that

by the end of 1992, EC government ministers had proposed sending prospective asylum seekers back to the first "safe" country they transited on their way to Western Europe. Germany has separately negotiated agreements with Romania and Bulgaria to return rejected asylum seekers in exchange for financial incentives and has indicated its intention to reach similar agreements with Poland, Czechoslovakia, and Hungary (Beyond Charity: International Cooperation and the Global Refugee Crisis, 1993, 126).

Previously in Canada there had been vague reference to the need for a committee to advise the Minister on proscribing countries that would be "safe" (the Immigration Act 1976-77, c. 52, s. 114(5)). In c-86 the legislators have been more forthright, "prescribing, for the purpose of sharing responsibility for the examination of persons who claim to be Convention refugees, countries that comply with Article 33 ["Prohibition of expulsion or return - Refoulement"] of the Convention" (R.S. c.28, 4th supp., ss. 29(3),(4)). This could be interpreted to mean that if you leave your coun- try of origin, whatever the circumstances, and you stop over in one or several "safe" countries while en route, then you will be returned to one of those countries through which you passed. As a result, many asylum seekers would be stopped en route through a transit country because of visa requirements - another barrier to safe transit, particularly for countries (like Canada) that are far afield from many claim countries and therefore less likely to be on direct flight routes. So once again, although in apparent violation of the spirit (if not the letter) of the Universal Declaration of Human Rights, the Convention relating to the Status of Refugees, the Protocol to the Convention, and the Declaration on Territorial Asylum, this clause (and others like it) has been invoked and utilized with a high degree of success to limit the flow of refugees, in particular those moving from the Third to the First World. These clauses are particularly nefarious in Europe, given the number of flights that necessarily stop there, and it seems to violate a number of Council of Europe recommendations, including Recommendation 434 (1965), article 11 (ii and iii); Resolution 14 (1967), articles 1 and 2; Recommendation 773 (1976), section II; Recommendation 817 (1977), article 14; the Declaration on Territorial Asylum (1977); and Recommendation $\mathrm{R}$ (1981), sections 1 to 6 . If the tenets of such a clause were to be invoked, particularly in a systematic fashion by important "turnstile" airports such as Amsterdam-Schiphol, London-Heathrow, Geneva-Cointrin, and Zürich-Kloten, then the possibility that persons could flee from persecution with the hope of asylum in a safe country that is far from the country of origin would be significantly diminished, particularly for the poor and the disenfranchised.

\section{Conclusion}

It would be pointless to reiterate the obvious, that Bill c-31 is simply further evidence of a quest for power and a hatred of any other that doesn't provide a positive reflection of what we are sending off as Canadian standards to everyone who comes knocking at our door. What is wrong with "safe third country" clauses is what is wrong with immigration acts generally speaking: they are designed to keep out the people we are supposed to be helping. Examples abound, but a few might show just how our immigrationresistant walls are erected. Persecuted persons rarely have the material means, the documentation, or the connections needed to make direct flights abroad. Members of the People's Party of Pakistan fleeing persecution from the sympathizers of the Muslim-League Party in the Punjab, for example, are forced to take overland routes to (say) India to flee their oppressors, just as persons fleeing government 
agents in (say) Togo, take overland routes to Ghana (and vice-versa), Russian Jews fleeing the long arm of Pamyat (the notorious anti-Semitic organization that emerged in the mid-1980s) could take overland routes to Europe, and so forth. But persecution seldom ends in neighbouring countries, for the arm of persecuting authorities is often long enough to extend beyond its borders; it is often the case that the source of persecution in a country of origin continues to be a source of persecution in a neighbouring country (Ahmadi Muslims in Pakistan will not find India any more welcoming, Jews in Kazakhstan will not find Russia any less anti-Semitic, Russian half-Jews in Israel will not find much comfort in Syria, and so forth). The "third country" clause, by acting against persecuted persons who don't have the means to seek asylum in the First World, keeps the results of First World intervention, Third World dictatorial practices, regional conflicts, and home-grown oppression within the confines of the state in question, or at least restricts its spread much beyond neighbouring countries.

As is always the case, the exceptions to the "third country" rule apply to those who can afford intercontinental travel documents and tickets with the proper (i.e., the most expensive) routing, just as the exceptions to the rule that it's hard to tell one's story in a way that we like to hear it, without the assistance of a hotshot lawyer, apply to those who can afford to shell out the big bucks. We shouldn't be surprised by any of this, given the nature of the economic system within which we live, but we ought perhaps to be, at least, disgusted.

Formerly a refugee researcher at the INRS in Montreal and a visiting fellow at Yale University, Robert Barsky is an associate professor at the University of Western Ontario. He is the author of books on Noam Chomsky and on literary theory, and has written two books on refugee studies: Constructing a Productive Other: Discourse Theory and the Convention Refugee Hearings and Arguing and Justifying: Assessing the Convention Refugee Choice of Moment, Motive and Host Country. 